\title{
Direct Renin Inhibition: Focus on Aliskiren
}

\author{
James L. Pool, MD
}

\begin{abstract}
BACKGROUND: Despite the availability of many effective, well-tolerated drugs, a significant proportion of treated hypertensive patients still have uncontrolled high blood pressure (BP) and thus face serious morbidity and mortality. The renin-angiotensin aldosterone system (RAAS) is a key target for BP control and for cardiovascular and renal protection. Renin controls the rate-limiting step in the RAAS cascade and hence is the optimal target for RAAS suppression. Aliskiren is the first direct renin inhibitor (DRI) to be approved by the U.S. Food and Drug Administration and the European Medicines Agency for treating hypertension.
\end{abstract}

OBJECTIVE: To provide an overview of the pharmacology, pharmacokinetics, preclinical, and clinical efficacy and safety data on the DRI aliskiren.

RESULTS: Approximately $70 \%$ of essential hypertension is associated with elevated renin levels. Aliskiren is a potent and highly specific inhibitor of renin, with oral bioavailability of $2.6 \%$ and an elimination half-life of 40 hours, making it suitable for once-daily oral administration. Aliskiren dose-dependently reduced BP, inhibited plasma renin activity (PRA), attenuated renal damage in animal models, and showed efficient and longer-lasting blockade of the RAAS in normotensive human subjects compared with other RAAS inhibitors. The clinical efficacy and safety of aliskiren have been evaluated both as monotherapy and in combination with other antihypertensive agents in phase II and phase III trials of patients with mild to severe hypertension. When used as monotherapy, aliskiren led to significant dose-dependent reductions in BP from baseline that were greater than those obtained with placebo and comparable with those achieved with an angiotensin II receptor blocker (ARB). The combination of aliskiren with a diuretic, a calcium channel blocker (CCB), an angiotensin-converting enzyme inhibitor (ACEI), or an ARB generally had greater and longer-lasting BP-lowering efficacy than did single agents alone. Aliskiren also countered the reactive increase in PRA caused by diuretic, CCB, ACEI, and ARB therapy. Once-daily treatment with aliskiren was well tolerated.

CONCLUSIONS: As a DRI, aliskiren blocks the RAAS more completely than do other current downstream RAAS inhibitors. When used once daily, aliskiren is a safe and effective antihypertensive agent that can be used as monotherapy or in combination with other agents to provide additional options to improve BP control.

KEYWORDS: Aliskiren, Antihypertensives, Renin

J Manag Care Pharm. 2007;13(8)(suppl S-b):S21-S33

Copyright@ 2007, Academy of Managed Care Pharmacy. All rights reserved.

Author

JAMES L. POOL, MD, is a professor, medicine and pharmacology, Baylor College of Medicine, Houston, TX, and holds the James L. Pool Endowed Chair in Clinical Pharmacology. He is also the clinical director, Hypertension-Clinical Pharmacology Research Clinic, at Baylor.

AUTHOR CORRESPONDENCE: James L. Pool, MD, Baylor College of Medicine, Houston, TX 77030; Tel: (713) 798-0180; E-mail: jpool@bcm.edu
T he renin-angiotensin aldosterone system (RAAS) is a coordinated hormonal cascade that governs cardiovascular, renal, and adrenal functions by regulating fluid and electrolyte balance as well as arterial pressure. ${ }^{1}$ The RAAS regulates blood pressure (BP) via angiotensin release and body electrolyte content via aldosterone release. ${ }^{2}$ Angiotensin (Ang) II is the principal effector hormone of the RAAS and is produced when renin acts on angiotensinogen to form Ang I, which is subsequently converted to the biologically active Ang II via the angiotensin-converting enzyme (ACE) ${ }^{3}$ The "traditional" concept of the RAAS has expanded over the years to include local tissue RAASs in the heart, brain, kidney, pancreas, and peripheral vasculature, which act as paracrine or autocrine systems that regulate vascular function and cell growth and contribute to the pathogenesis of cardiovascular and renal diseases. ${ }^{4,5}$

Inhibition of RAAS activity with ACE inhibitors (ACEIs) or angiotensin receptor blockers (ARBs) has proven effective for not only controlling hypertension but also delaying the onset of diabetes mellitus, slowing renal damage in patients with hypertension, and reversing left ventricular hypertrophy. ${ }^{6}$ However, these agents are no more effective than other antihypertensive agents in reducing major cardiovascular events, ${ }^{6}$ which suggests an incomplete blockade of the RAAS. Inhibition of Ang II formation or action via ACEIs or ARBs does not provide optimal suppression of RAAS activity, because a compensatory increase in renin concentrations again increases Ang I and Ang II levels. Ang II can also be formed using pathways that do not involve ACE. ${ }^{4}$

Because it causes the conversion of angiotensinogen to Ang I, which is the rate-limiting step in the RAAS cascade, renin is the main determinant of RAAS activity and has been considered for at least 50 years the optimal target for RAAS suppression. ${ }^{7}$ Circulating renin can be taken up by cardiac and coronary tissues, leading to the long-lasting generation of Ang II via ACE and non-ACE activity that is only partially suppressed by an ACEI. ${ }^{8}$ Inhibition of renin would favor more complete blockade of the system. The successful production of a highly potent, selective, clinically effective oral renin inhibitor is a major development in the area of RAAS inhibition. This article provides an overview of direct renin inhibition (DRI) and reviews the pharmacologic and clinical profile of aliskiren, the first antihypertensive agent in a new class of drugs approved by the U.S. Food and Drug Administration (FDA) in more than 10 years. Aliskiren also received approval from the European Medicines Agency (EMEA). 


\section{Renin}

Overactivity of the RAAS with high renin, Ang, and aldosterone levels causes fatal malignant hypertension and renovascular hypertension, whereas overactivity of the RAAS with milder elevations of renin levels has been associated with up to 70\% of cases of essential hypertension. ${ }^{2}$ Patients with plasma renin activity (PRA) levels exceeding $0.65 \mathrm{ng} / \mathrm{mL} / \mathrm{h}$ have renin-mediated hypertension, and those with lower PRA levels have salt hypertension, which accounts for the remaining 30\% of essential hypertension. ${ }^{2}$

Renin is an aspartyl protease that is synthesized as prorenin, a proenzyme that is transformed into renin by cleavage of a 43-amino-acid segment from the N-terminal end (Figure 1). This activation process, which occurs exclusively in the juxtaglomerular cells of the kidney, is followed by the release of renin into the circulation system. ${ }^{9}$ Although it is synthesized in only a few tissues (eyes, adrenal glands, testes, ovaries, and brain), prorenin represents between $70 \%$ and $90 \%$ of the total plasma renin in individuals without diabetes and as much as $95 \%$ of the total plasma renin in individuals with diabetes..$^{10}$ The local actions of renin are thus mediated by kidney-derived renin that is released into the circulation system and taken up by tissues. For example, cardiac Ang production depends on the conversion of angiotensinogen in extracellular fluid by plasma-derived renin. ${ }^{11}$

Renin receptors have been localized to glomerular mesangium and vascular smooth muscle cells within the subendothelium of glomerular and coronary arteries. ${ }^{9}$ The receptor colocalizes with renin. Cells transfected with receptor cDNA result in the expression of a membrane protein that specifically binds renin and prorenin with high affinity. ${ }^{9}$ Labeling studies have demonstrated high-affinity binding $\left(\mathrm{K}_{\mathrm{d}}=0.4 \mathrm{nM}\right)$ of renin to receptors on cultured human mesangial cells. ${ }^{12}$

The binding of renin to its receptor with a single transmembrane domain has multiple and far-reaching consequences. Receptor binding induces a 4 -fold increase in the catalytic conversion of angiotensinogen to Ang I, suggesting that the cell surface is an important site of Ang generation. ${ }^{9}$ Once bound, renin triggers a series of intracellular events that culminate in activation of the mitogen-activated protein kinases ERK1 (p44) and ERK2 (p42), which are involved in cell hypertrophy and proliferation. ${ }^{9}$ At physiologic levels, renin enhances the incorporation of ${ }^{3} \mathrm{H}$-thymidine into cells, with no increase in cell numbers; increases transforming growth factor beta in mesangial cells (suggesting upregulation through a receptor-mediated mechanism, independent of Ang II generation or action); and activates the synthesis of plasminogen activator- 1 and fibrotic extracellular components such as fibronectin and collagen (suggesting that renin may contribute to fibrotic disease). ${ }^{13,14}$ Overexpression of the renin receptor in arterial smooth muscle cells of transgenic rats resulted in high BP levels, increased heart rate, and significant elevation of plasma aldosterone levels, effects that were attributed to local activation of the intraadrenal RAAS..$^{15}$
When bound to the renin receptor, the catalytic activity of prorenin is comparable with that of renin and appears to be of pathologic significance. ${ }^{9}$ Elevated prorenin levels have been correlated with microvascular complications of diabetes, and lesions mimicking diabetic nephrosclerosis are present in transgenic rats expressing prorenin. ${ }^{16}$ Rats with streptozocin-induced diabetes have high levels of prorenin, Ang I, and Ang II, but not of renin, ACE, or angiotensinogen. ${ }^{16}$ Nonproteolytic activation of prorenin to its enzymatically active state occurs through the binding of certain carbohydrate substances or the renin receptor. When nonproteolytic conversion of prorenin was inhibited with a blocking peptide, levels of renal Ang I and Ang II were reduced and the development of nephropathy was attenuated, thus substantiating that prorenin has a role in the progression of diabetic renal damage ${ }^{16}$ How prorenin contributes to the pathophysiology of these complications remains to be established.

\section{Direct Renin Inhibition}

The concept of blocking the RAAS at its origin by inhibiting renin has existed for at least 50 years. The first synthetic renin inhibitor was pepstatin, which was followed by first-generation agents that were active but required parenteral administration. ${ }^{17}$ Oral agents that were subsequently developed, such as enalkiren, remikiren, and zankiren, had limited clinical use because they demonstrated poor bioavailability $(<2 \%)$, short half-lives, and weak antihypertensive activity. ${ }^{17}$ Crystal structure analyses of renin-inhibitor complexes and computational molecular modeling were later used to design selective nonpeptide DRIs that lacked the extended peptide-like backbone of previous inhibitors and had improved pharmacokinetic properties. ${ }^{18}$ Aliskiren is the first of these new nonpeptide DRIs to be approved by the FDA for the treatment of hypertension. It is administered once daily, either as monotherapy or in combination with other antihypertensive agents. In Europe, aliskiren received approval from the EMEA for the treatment of hypertension.

\section{Aliskiren}

Aliskiren is a transition-state mimetic agent with high hydrophilicity, which improves its oral bioavailability ${ }^{18}$ It is a highly potent inhibitor of renin $(\mathrm{IC} 50=0.6 \mathrm{nM})$ with a high affinity for renin and a high species specificity for primate renin. Aliskiren inhibits human, marmoset, and rat plasma renin with IC50 values of $0.6 \mathrm{nmol}$ per L, $2.0 \mathrm{nmol}$ per L, and $80 \mathrm{nmol}$ per L, respectively. ${ }^{18}$ Therefore, preclinical testing has been performed in sodium-depleted marmosets and in spontaneously hypertensive rats.

In sodium-depleted marmosets, doses of aliskiren ranging from $0.3 \mathrm{mg}$ per $\mathrm{kg}$ to $10 \mathrm{mg}$ per $\mathrm{kg}$ caused a dose-dependent reduction in mean arterial BP. ${ }^{19}$ All doses of aliskiren completely inhibited PRA within 1.5 hours of administration, and this inhibition was sustained for more than 24 hours with the $3 \mathrm{mg}$ per $\mathrm{kg}$ and $10 \mathrm{mg}$ per $\mathrm{kg}$ doses. ${ }^{19}$ When the $3 \mathrm{mg}$ per $\mathrm{kg}$ dose was 

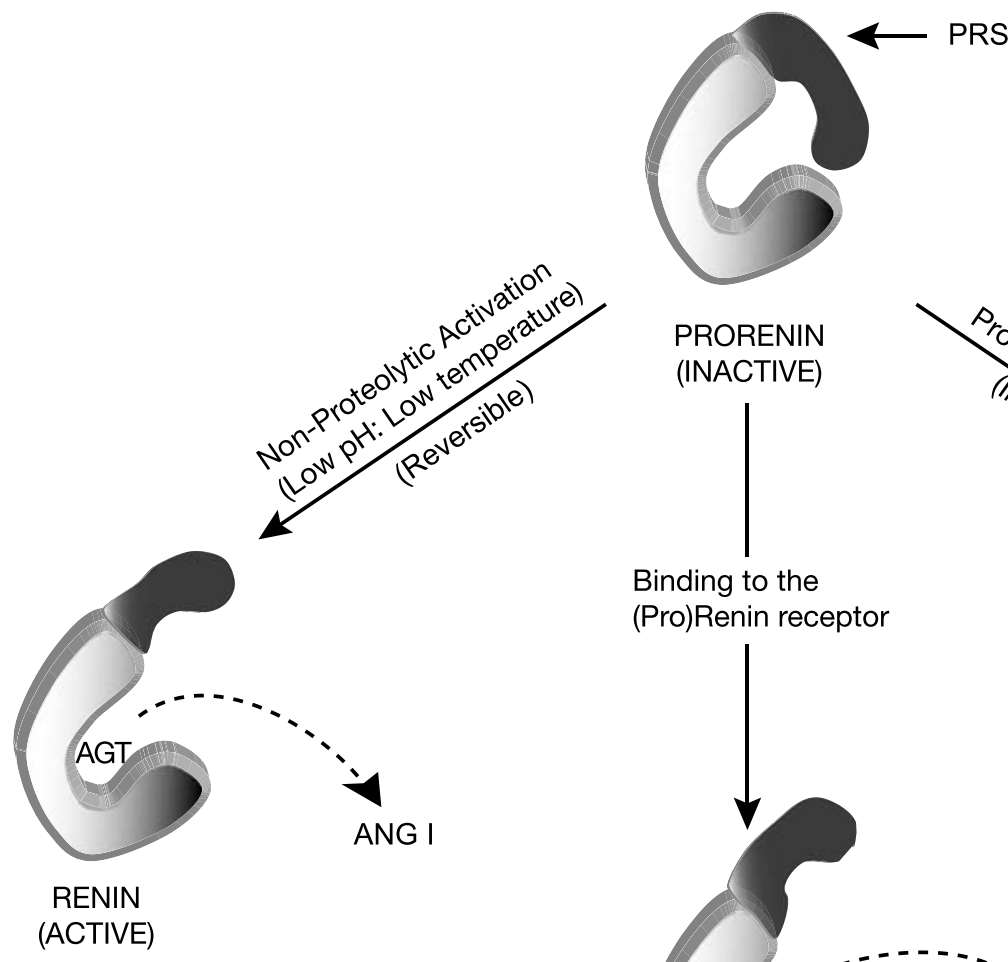

(INACTIVE)

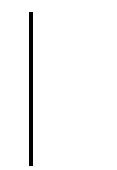

Binding to the

(Pro)Renin receptor
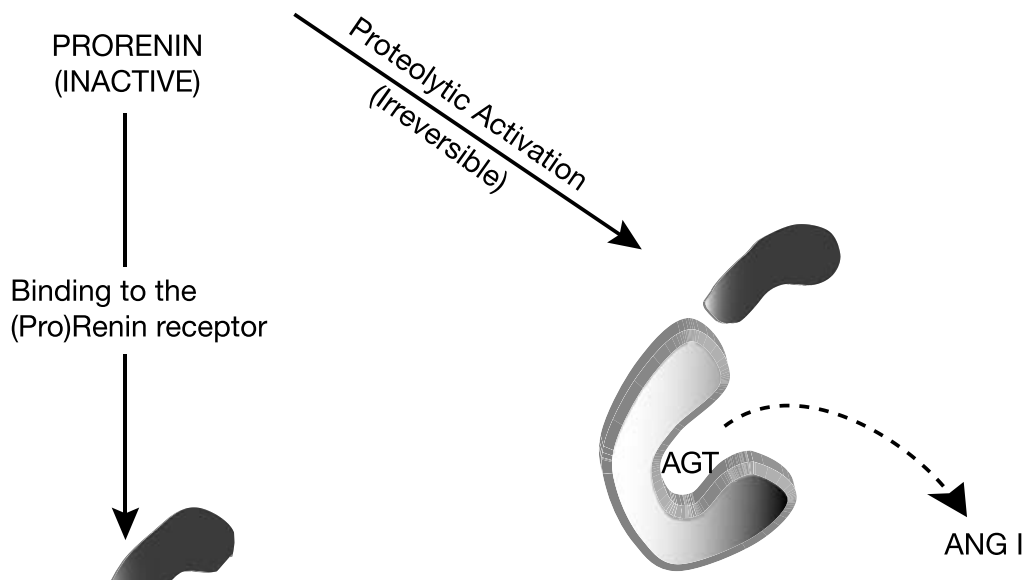

RENIN

(ACTIVE)

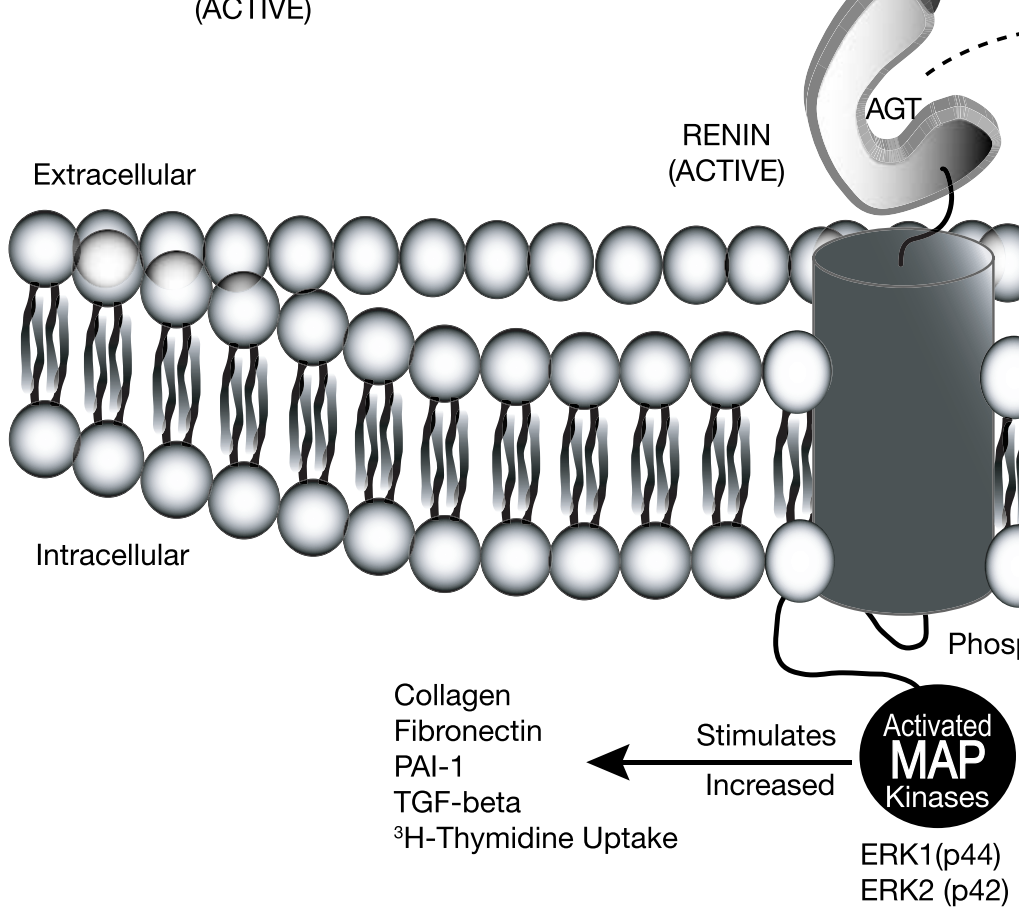

$A G T=$ angiotensinogen; $A N G I=$ angiotensin $I ; M A P=$ mitogen-activated protein; $P A I=$ plasminogen activator inhibitor; $P R S=$ prorenin segment; TGF=transforming growth factor. 
administered, BP was reduced by a maximum of $30 \mathrm{~mm} \mathrm{Hg}$ without any effect on heart rate. The $10 \mathrm{mg}$ per $\mathrm{kg}$ dose of aliskiren was more effective than similar doses of either benazepril or valsartan in reducing mean arterial pressure. ${ }^{19}$

Pilz and colleagues compared the effects of subcutaneous aliskiren $0.3 \mathrm{mg}$ per $\mathrm{kg}$ per day, $3 \mathrm{mg}$ per $\mathrm{kg}$ per day with valsartan $1 \mathrm{mg}$ per kg per day, and $10 \mathrm{mg}$ per kg per day with no treatment on the development of end-organ damage in hypertensive double-transgenic rats with high levels of serum creatinine and albuminuria. ${ }^{20}$ Both doses of aliskiren and the higher dose of valsartan reduced renal Ang I and II content, maintained creatinine at normal levels, decreased albuminuria, prevented renal infiltration with inflammatory cells, reduced cardiac hypertrophy, and prolonged survival. ${ }^{20}$ However, aliskiren $3 \mathrm{mg}$ per $\mathrm{kg}$ per day was significantly more effective than valsartan $10 \mathrm{mg}$ per kg per day in reducing systolic BP (SBP), cardiac hypertrophy, and left ventricular wall thickness $\left(P<0.05\right.$ for all endpoints) ${ }^{20}$ In this model, renin inhibition compared favorably with $\mathrm{AT}_{1}$ receptor blockade in reversing renal damage.

Subsequent studies in normotensive human subjects demonstrated efficient blockade of the RAAS with aliskiren. In 18 normotensive men with a sodium intake of $100 \mathrm{mmol} /$ day, treatment with aliskiren ( $40 \mathrm{mg}$ per day to $640 \mathrm{mg}$ per day) for 8 days significantly and in a dose-dependent manner suppressed PRA and plasma concentrations of Ang I and Ang II. ${ }^{21}$ Maximal reduction of Ang II occurred within 1 hour of the administration of aliskiren, compared with 6 hours with a $20 \mathrm{mg}$ dose of enalapril. The level of inhibition of Ang II by enalapril (57\%) was similar to that with a $160 \mathrm{mg}$ dose of aliskiren (56\%). ${ }^{21}$ A dose of aliskiren $\geq 80 \mathrm{mg}$ reduced plasma aldosterone levels within 3 hours of administration and, at the highest dose, these levels remained suppressed for up to 24 hours. ${ }^{21}$ In response to the reduction in Ang II level, plasma renin concentrations increased similarly with aliskiren $160 \mathrm{mg}$ and enalapril $20 \mathrm{mg} .^{21}$

A double-blind, placebo-controlled, randomized, 4-period crossover study in 12 normotensive men who were mildly sodium depleted compared a single high dose of aliskiren (300 mg), a standard dose of valsartan (160 mg), and their combination at half doses (aliskiren $150 \mathrm{mg}$ plus valsartan $80 \mathrm{mg}$ ). ${ }^{22}$ In contrast to valsartan, aliskiren decreased PRA and Ang I and Ang II levels for 48 hours, inhibited urinary aldosterone secretion for a longer period, and resulted in greater and longer-lasting increases in plasma renin levels. ${ }^{22}$ In general, the effects of the low-dose combination were similar to those of aliskiren $300 \mathrm{mg}$ than to those of valsartan $160 \mathrm{mg}$. The combination blunted the valsartaninduced increase in PRA and Ang I and Ang II concentrations, led to greater and longer suppression of urinary aldosterone excretion compared with valsartan alone, and was as effective as either monotherapy in reducing BP. ${ }^{22}$ The longer duration of RAAS inhibition by aliskiren compared with valsartan suggested that the effects of Ang II may be reduced more effectively by direct renin inhibition than by Ang receptor blockade.

\section{Aliskiren Pharmacokinetics}

The pharmacokinetics of aliskiren deviate from dose linearity, with an overproportional increase in area under the curve (AUC) and $C_{\max }$ with respect to the administered dose. ${ }^{22}$ The mean terminal half-life is approximately 40 hours after multiple administrations of a single dose, and repeated once-daily administration leads to drug accumulation. ${ }^{23}$ The mean absolute bioavailability is $2.6 \%{ }^{24}$; administration with a high-fat meal reduces AUC and $\mathrm{C}_{\max }$ values by $71 \%$ and $85 \%$, respectively, of those in the fasting state, so patients should be advised to take aliskiren in the same manner each day with respect to meal times. ${ }^{25}$ Peak plasma concentrations are reached 1 to 2 hours after dosing, ${ }^{23,24}$ and steady state is reached after 5 to 8 days of once-daily administration. ${ }^{21}$

The main pathway of elimination for aliskiren is via biliary excretion as unmetabolized drug. Less than $1 \%$ of an orally administered dose is excreted in urine. ${ }^{21}$ Aliskiren is not metabolized by, and does not induce or inhibit, cytochrome P450 enzymes and shows no clinically relevant pharmacokinetic interactions with warfarin, ${ }^{17}$ lovastatin, ${ }^{26}$ atenolol, ${ }^{26}$ celecoxib, ${ }^{26}$ cimetidine, ${ }^{26}$ amlodipine, ${ }^{27}$ valsartan, ${ }^{27}$ hydrochlorothiazide (HCTZ) ${ }^{27}$ or ramipril. ${ }^{27}$ Coadministration of aliskiren with furosemide, a commonly used loop diuretic, reduced the AUC of furosemide by $28 \%$ and $C_{\max }$ by $49 \%$, but the clinical significance of this remains uncertain. ${ }^{28}$ The pharmacokinetics of aliskiren remain unaffected by ethnicity, ${ }^{24}$ age,${ }^{29}$ gender ${ }^{23}$ hepatic impairment, ${ }^{30}$ renal impairment, ${ }^{31}$ and diabetes. ${ }^{23}$

\section{Studies in Patients With Hypertension}

Phase II and III clinical trials have demonstrated the efficacy of once-daily administration of aliskiren in the treatment of patients with mild to moderate hypertension (diastolic blood pressure $[\mathrm{DBP}] \geq 95 \mathrm{~mm} \mathrm{Hg}$ and $<110 \mathrm{~mm} \mathrm{Hg}$, either as monotherapy or in combination with diuretics, calcium channel blockers [CCBs], ACEIs, or ARBs), or as monotherapy in the treatment of severe hypertension (DBP $\geq 105 \mathrm{~mm} \mathrm{Hg}$ and $<120 \mathrm{~mm} \mathrm{Hg}$ ). Two trials that evaluated both monotherapy and combination therapy with aliskiren are discussed below in Combination Therapy. ${ }^{32,33}$ Table 1 provides details of the study design and the main findings of all the trials that are discussed.

\section{Monotherapy}

In a 4-week study, aliskiren $37.5 \mathrm{mg}, 75 \mathrm{mg}, 150 \mathrm{mg}$, or $300 \mathrm{mg}$ once daily was compared with losartan $100 \mathrm{mg}$ once a day. ${ }^{34}$ Dose-dependent reductions from baseline in daytime ambulatory SBP (ASBP) were obtained with all doses of aliskiren $(P=0.0002$ vs. baseline for all doses). ${ }^{34}$ The changes in daytime ASBP with the 3 highest doses of aliskiren were similar to those obtained with losartan $100 \mathrm{mg},{ }^{34}$ and the heart rate remained unaltered. All doses of aliskiren also led to significant dose-dependent decreases of PRA between $-55 \%$ and $-83 \%$ ( $P=0.0008$ vs. baseline), whereas PRA increased by $110 \%$ with losartan. ${ }^{34}$ 
Table 1 (continued)_Phase II and III Double-Blind Clinical Trials of Once-Daily Aliskiren Treatment in Patients With Mild to Moderate Hypertension

\begin{tabular}{|c|c|c|c|c|c|c|}
\hline Study & $\begin{array}{l}\text { Study Design (Number of } \\
\text { Patients Randomized; Mean Age) }\end{array}$ & Treatments/ Duration* & \multicolumn{4}{|c|}{$\begin{array}{c}\text { Effects of Aliskiren on Primary Efficacy Variable } \\
\text { (Statistical Significance) }\end{array}$} \\
\hline \multicolumn{7}{|c|}{ Combination Therapy (continued) } \\
\hline $\begin{array}{l}\text { Uresin et al. }{ }^{40} \\
\text { (2006) }\end{array}$ & $\begin{array}{l}\text { r, db ( } 837 ; 59.8 \text { years) } \\
\text { Patients with type } 1 \text { or type } 2 \\
\text { diabetes }\end{array}$ & $\begin{array}{l}\text { Aliskiren } 300 \mathrm{mg} \\
\text { Ramipril } 10 \mathrm{mg} \\
\text { Aliskiren/ramipril 300/10 mg }\end{array}$ & $\begin{array}{l}\text { Reductions from baseline } \\
\text { A300 mg: } \\
\text { R10 mg: } \\
\text { A300 mg/R10 mg: }\end{array}$ & $\begin{array}{l}\text { P/MSDBP } \\
-14.7 /-11 \\
-12.0 /-10 \\
-16.6 /-12\end{array}$ & $\mathrm{~mm} \mathrm{Hg})$ & \\
\hline $\begin{array}{l}\text { Pool et al. }{ }^{33} \\
(2007) \ddagger\end{array}$ & $\mathrm{r}, \mathrm{db}, \mathrm{pc}(1,123 ; 56$ years $)$ & $\begin{array}{l}\text { Aliskiren } 75 \mathrm{mg}, 150 \mathrm{mg}, 300 \mathrm{mg} \\
\text { Valsartan } 80 \mathrm{mg}, 160 \mathrm{mg} \text {, or } \\
320 \mathrm{mg} \\
\text { Aliskiren (150 mg, } 300 \mathrm{mg} \text {, or } \\
600 \mathrm{mg} \text { ) } \\
\text { Aliskiren/valsartan } 75 \mathrm{mg} / 80 \mathrm{mg} \text {, } \\
150 \mathrm{mg} / 160 \mathrm{mg}, 300 \mathrm{mg} / 320 \mathrm{mg} \\
\text { Valsartan/HCTZ } 160 \mathrm{mg} / 12.5 \mathrm{mg} \\
\text { Placebo } \\
8 \text { weeks }\end{array}$ & $\begin{array}{l}\text { Lowers MSDBP (aliskiren } \\
\text { Aliskiren= valsartan } \\
\text { Lowers MSDBP }(P<0.05 \mathrm{v} \\
\text { aliskiren/valsartan = valsa } \\
\text { ference) } \\
\text { Reductions from baseline } \\
\text { A75 mg: } \\
\text { A150 mg: } \\
\text { A300 mg: } \\
\text { V80 mg: } \\
\text { V160 mg: } \\
\text { V320 mg: } \\
\text { A75 mg/V80 mg: } \\
\text { A150 mg/V160 mg: } \\
\text { A300 mg/V320 mg: } \\
\text { V160 mg/HCTZ12.5 mg: } \\
\text { Placebo: }\end{array}$ & $\begin{array}{l}00 \mathrm{mg} ; P< \\
\text { placebo), } \\
\text { an/HCTZ } \\
\text { in: } \\
\text { MSSBP } \\
\text { ASDBP (mr } \\
-12.1 /-10 \\
-12.1 /-10 \\
-15.0 /-12 \\
-11.2 /-10 \\
-15.5 /-11 \\
-16.5 /-11 \\
-14.5 /-11 \\
-16.6 /-12 \\
-18.0 /-12 \\
-18.9 /-13 \\
-10.0 /-8 .\end{array}$ & 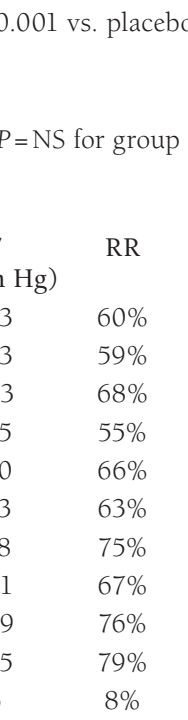 & $\begin{array}{l}\text { dif- } \\
\\
\text { CR } \\
\\
\\
36 \% \\
31 \% \\
42 \% \\
38 \% \\
47 \% \\
42 \% \\
43 \% \\
37 \% \\
50 \% \\
55 \% \\
28 \%\end{array}$ \\
\hline $\begin{array}{l}\text { Oparil et al. }{ }^{41} \\
(2007)\end{array}$ & r, db, pc $(1,797 ; 52.3$ years $)$ & $\begin{array}{l}\text { Aliskiren } 300 \mathrm{mg} \\
\text { Valsartan } 320 \mathrm{mg} \\
\text { Aliskiren/valsartan } 300 \mathrm{mg} / \\
320 \mathrm{mg} \\
\text { Placebo } \\
8 \text { weeks }\end{array}$ & \multicolumn{4}{|c|}{ 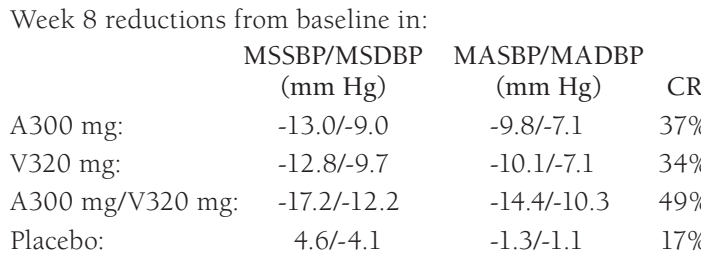 } \\
\hline
\end{tabular}

*All treatments were administered once daily.

$\uparrow$ This trial evaluated the efficacy of aliskiren as monotherapy and in combination with HCTZ. A total of 2,776 patients were randomized to placebo ( $n=195)$; aliskiren $75 \mathrm{mg}, 150 \mathrm{mg}$, $300 \mathrm{mg}$ monotherapy ( $n=184$, 185, 183); HCTZ $6.25 \mathrm{mg}, 12.5 \mathrm{mg}, 25 \mathrm{mg}$ monotherapy ( $n=194$, 188, 176); or combination aliskiren/HCTZ therapy (75 mg/6.25 mg, $n=188 ; 75 \mathrm{mg} / 12.5 \mathrm{mg}, n=193 ; 75 \mathrm{mg} / 25 \mathrm{mg}, \mathrm{n}=186 ; 150 \mathrm{mg} / 6.25 \mathrm{mg}, n=176 ; 150 \mathrm{mg} / 12.5 \mathrm{mg}$, $n=186 ; 150 \mathrm{mg} / 25 \mathrm{mg}, n=188 ; 300 \mathrm{mg} / 12.5 \mathrm{mg}, n=181 ; 300 \mathrm{mg} / 25 \mathrm{mg}, n=173)$. The total number of patients given in the table includes the placebo group. \#This trial evaluated the efficacy of aliskiren as monotherapy (primary objective) and in combination with valsartan (secondary objective). A total of 1,123 patients were randomized to placebo $(n=177)$; aliskiren $75 \mathrm{mg}, 150 \mathrm{mg}, 300 \mathrm{mg}$ monotherapy $(n=179,178,175)$; valsartan $80 \mathrm{mg}, 160 \mathrm{mg}, 320 \mathrm{mg}$ monotherapy $(n=58,59,60)$; combination aliskiren/valsartan ( $75 \mathrm{mg} / 80 \mathrm{mg}, n=80 ; 150 \mathrm{mg} / 160 \mathrm{mg}, n=60 ; 300 \mathrm{mg} / 320 \mathrm{mg}, n=58)$; or combination valsartan/ HCTZ $160 \mathrm{mg} / 12.5 \mathrm{mg}$ (active control; $n=59$ ). The total number of patients given in the table includes the placebo group.

$A=$ aliskiren; $a c=$ active controlled/active comparator; $A S B P=$ ambulatory systolic blood pressure; $C R=$ control rate; $d b=$ double blind; HCTZ=hydrochlorothiazide; Ir =irbesartan; $L=$ losartan; $\mathrm{MADBP}=$ mean ambulatory diastolic pressure; $\mathrm{MASBP}=$ mean ambulatory systolic pressure; $\mathrm{MSDBP}=$ mean sitting diastolic blood pressure; $M S S B P=$ mean sitting systolic blood pressure; $N S=$ not significant; $p c=$ placebo controlled; $R=$ ramipril; $r=$ randomized; $R R=$ responder rate; $s b=s i n g l e ~ b l i n d ;$ $S B P=$ systolic blood pressure; $V=$ valsartan. 


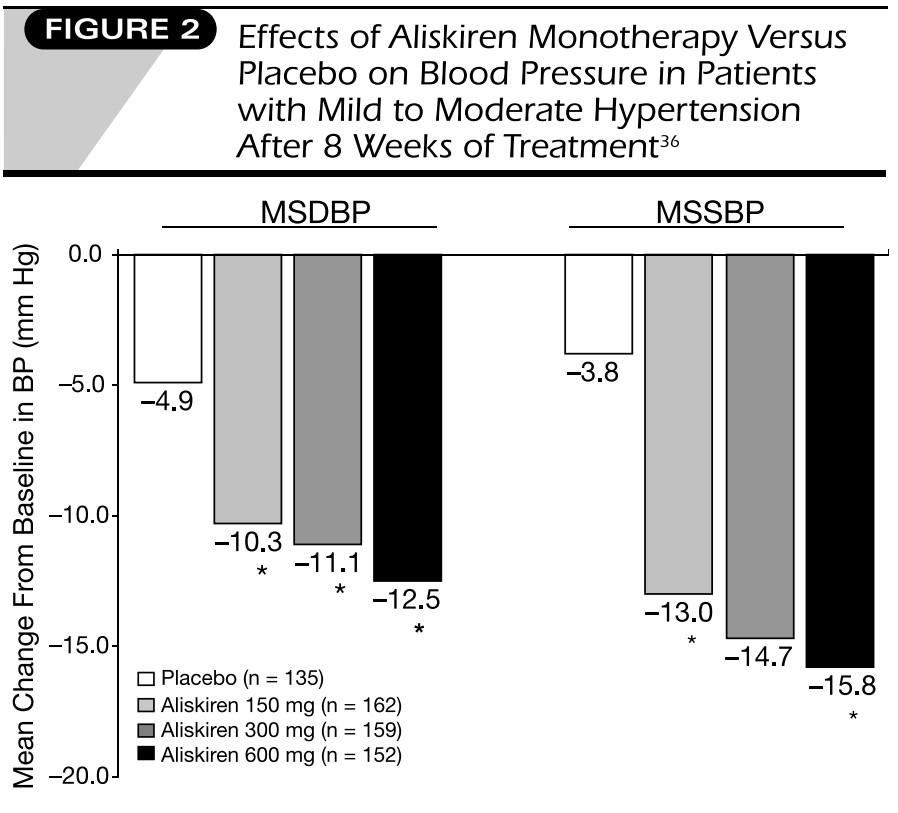

${ }^{*} P<0.0001$ versus placebo.

$M S D B P=$ mean sitting diastolic blood pressure; $M S S B P=$ mean sitting systolic blood pressure

daily in the treatment of uncomplicated severe hypertension (MSDBP $\geq 105 \mathrm{~mm} \mathrm{Hg}$ and $<120 \mathrm{~mm} \mathrm{Hg}$ ) ${ }^{37}$ If additional BP control was required, the dose of aliskiren or lisinopril could be doubled, with the option of adding HCTZ 25 mg once daily to the regimen. Titration to the higher dose of the antihypertensive occurred in $74 \%$ and $66 \%$ of the aliskiren and lisinopril groups, respectively. Rates of add-on therapy with HCTZ were similar between groups (aliskiren 54\%, lisinopril 45\%). Similar reductions in MSDBP were observed in the aliskiren and lisinopril groups.

\section{Combination Therapy}

Although BP may be controlled in some patients with aliskiren monotherapy, there is greater likelihood that combination therapy will be required to control BP in the majority of patients.

Two trials have evaluated the antihypertensive efficacy of aliskiren in combination with HCTZ, ${ }^{32,38}$ and 4 trials have studied the efficacy of dual RAAS inhibition with aliskiren and a $\mathrm{CCB},{ }^{39}$ an $\mathrm{ACEI},{ }^{40}$ or an ARB. ${ }^{33,41}$

Villamil and colleagues evaluated treatment with once-daily aliskiren $75 \mathrm{mg}, 150 \mathrm{mg}$, or $300 \mathrm{mg}$; HCTZ $6.25 \mathrm{mg}, 12.5 \mathrm{mg}$, or $25 \mathrm{mg}$; or their combinations (aliskiren/HCTZ: $75 \mathrm{mg} / 6.25 \mathrm{mg}$, $75 \mathrm{mg} / 12.5 \mathrm{mg}, 75 \mathrm{mg} / 25 \mathrm{mg}, 150 \mathrm{mg} / 6.25 \mathrm{mg}, 150 \mathrm{mg} /$ $12.5 \mathrm{mg}, 150 \mathrm{mg} / 25 \mathrm{mg}, 300 \mathrm{mg} / 12.5 \mathrm{mg}$, and $300 \mathrm{mg} / 25 \mathrm{mg}$ ) in an 8-week placebo-controlled study. ${ }^{32}$ Aliskiren $150 \mathrm{mg}$ and $300 \mathrm{mg}$, all doses of HCTZ, and all combinations were superior to placebo in reducing MSDBP levels $(P<0.0001){ }^{32}$ All combinations, with the exception of aliskiren/HCTZ $150 \mathrm{mg} /$
$6.25 \mathrm{mg}$ and $75 \mathrm{mg} / 12.5 \mathrm{mg}$, were also more effective than either monotherapy in reducing MSDBP and MSSBP levels $(P<0.05){ }^{32}$ Responder rates (the proportion of patients with MSDBP $<90 \mathrm{~mm} \mathrm{Hg}$ or $\geq 10 \mathrm{~mm} \mathrm{Hg}$ decrease from baseline) were significantly higher with aliskiren $300 \mathrm{mg}(P=0.0005)$, HCTZ $12.5 \mathrm{mg}$ and $25 \mathrm{mg}(P<0.02)$, and with all combinations $(P<0.05)$ than with placebo. ${ }^{32}$ Responder rates for all combinations of aliskiren with HCTZ $25 \mathrm{mg}$ and aliskiren/HCTZ $300 \mathrm{mg} / 12.5 \mathrm{mg}$ were significantly higher than for their respective monotherapies $(P<0.05)$. A higher proportion of subjects achieved BP control (MSSBP/MSDBP $<140 / 90 \mathrm{~mm} \mathrm{Hg}$ ) with combination therapy than with aliskiren or HCTZ monotherapy. ${ }^{32}$ Combinations containing higher doses of 1 or both drugs (aliskiren $150 \mathrm{mg}$ or $300 \mathrm{mg}$ or HCTZ $25 \mathrm{mg}$ ) yielded significantly higher control rates compared with monotherapy. ${ }^{32}$ Treatment with aliskiren resulted in a reduction of PRA of up to $65 \%$ from baseline. An increase in PRA of up to $72 \%$ with HCTZ was averted with the aliskiren/HCTZ combination. ${ }^{32}$ Plasma renin concentrations increased with aliskiren, with HCTZ $25 \mathrm{mg}$, and with all aliskiren/HCTZ combinations. ${ }^{32}$ An additional effect of combination therapy was a reduction in the incidence of hypokalemia compared with the patients receiving HCTZ monotherapy. ${ }^{32}$

The effects of adding aliskiren $150 \mathrm{mg}$ once daily to amlodipine $5 \mathrm{mg}$ once daily in patients whose hypertension was not fully controlled with CCB monotherapy was compared with continuing treatment with amlodipine $5 \mathrm{mg}$ or $10 \mathrm{mg}$ once daily alone. ${ }^{39}$ At 6 weeks, patients who were treated with aliskiren $150 \mathrm{mg}$ plus amlodipine $5 \mathrm{mg}$ had significant additional reductions in MSDBP and MSSBP compared with patients who were treated with amlodipine $5 \mathrm{mg}$ alone (mean change, in $\mathrm{mm} \mathrm{Hg},-8.5$ and -4.8 for MSDBP, respectively, and -11.0 and -5.0 for MSSBP, respectively; $P<0.0001) .{ }^{39}$ The proportion of patients who achieved a MSDBP of $<90 \mathrm{~mm} \mathrm{Hg}$ and/or at least a $10 \mathrm{~mm} \mathrm{Hg}$ reduction from baseline was significantly greater for those treated with aliskiren $150 \mathrm{mg}$ plus amlodipine $5 \mathrm{mg}$ compared with amlodipine $5 \mathrm{mg}$ alone (64.2\% and $45.2 \%$, respectively, $P=0.0005$ ). In addition, a significantly greater proportion of patients who were treated with aliskiren $150 \mathrm{mg}$ plus amlodipine $5 \mathrm{mg}$ achieved BP levels of $<140 \mathrm{~mm} \mathrm{Hg} / 90 \mathrm{~mm} \mathrm{Hg}$ compared with amlodipine $5 \mathrm{mg}$ alone (42.8\% and 22.6\%, respectively, $\mathrm{P}<0.0001) .{ }^{39}$ The additional efficacy resulting from adding aliskiren to amlodipine therapy was comparable with that achieved by doubling the dose of amlodipine to $10 \mathrm{mg}$, but combination therapy was not associated with the increased incidence of edema that was reported with high-dose amlodipine treatment. ${ }^{39}$

The effect of 12 weeks of add-on therapy with once-daily aliskiren $300 \mathrm{mg}$, irbesartan $300 \mathrm{mg}$, or amlodipine $10 \mathrm{mg}$, or placebo was studied in hypertensive obese patients who were unresponsive to 4 weeks of initial treatment with HCTZ 25 mg. ${ }^{38}$ At 8 weeks, the aliskiren/HCTZ combination reduced MSDBP and MSSBP significantly more than did HCTZ (mean 
treatment difference, $-4.0 \mathrm{~mm} \mathrm{Hg}$ and $-7.2 \mathrm{~mm} \mathrm{Hg}$, respectively; $\mathrm{P}<0.0001){ }^{38}$ Reductions in $\mathrm{BP}$ with the combination regimen of aliskiren and HCTZ were comparable with reductions with irbesartan and HCTZ or with amlodipine and HCTZ. ${ }^{38}$ Responder rates and BP control rates were higher in patients who were switched to the aliskiren/HCTZ combination than in those continuing on HCTZ alone (week 12 responder rate of $76 \%$ vs. $58 \%$ $[P=0.004]$ and control rate of $58 \%$ vs. $33 \%[P=0.0001]) .{ }^{38}$

A phase III study evaluated the use of aliskiren alone or in combination with the ACEI ramipril for managing hypertension in patients with type 1 or 2 diabetes mellitus. ${ }^{40}$ Patients were randomized and forced-titrated to receive once-daily aliskiren $300 \mathrm{mg}$, ramipril $10 \mathrm{mg}$, or aliskiren/ramipril in combination $300 \mathrm{mg} / 10 \mathrm{mg}$ for 8 weeks. Reductions in MSSBP and MSDBP with aliskiren, ramipril, and aliskiren/ramipril were $14.7 \mathrm{~mm}$ $\mathrm{Hg} / 11.3 \mathrm{~mm} \mathrm{Hg}, 12.0 \mathrm{~mm} \mathrm{Hg} / 10.7 \mathrm{~mm} \mathrm{Hg}$, and $16.6 \mathrm{~mm}$ $\mathrm{Hg} / 12.8 \mathrm{~mm} \mathrm{Hg}$, respectively (Figure 3a). A reactive increase in PRA of $111 \%$ after ramipril treatment was countered by aliskiren in patients receiving combination therapy, leading to an overall $44 \%$ reduction in PRA. These findings suggest that aliskiren, by enhancing RAAS blockade when added to an ACEI, provides additional antihypertensive efficacy in patients with diabetes and hypertension.

Pool and colleagues ${ }^{33}$ studied the first-ever combination of a DRI and an ARB. In a primary safety and tolerability study, the once-daily antihypertensive efficacy of aliskiren alone (75 mg, $150 \mathrm{mg}$, and $300 \mathrm{mg}$ ), valsartan alone (80 mg, $160 \mathrm{mg}$, and $320 \mathrm{mg}$ ), aliskiren/valsartan combinations (75 mg/80 mg, $150 \mathrm{mg} / 160 \mathrm{mg}$, and $300 \mathrm{mg} / 320 \mathrm{mg}$ ), and valsartan/HCTZ (160 mg/12.5 mg) was evaluated. ${ }^{33}$ Aliskiren $300 \mathrm{mg}$ once daily significantly reduced MSDBP and MSSBP levels compared with placebo $(P<0.0001)$. The magnitude of BP reduction was similar for aliskiren and valsartan across all dose ranges. ${ }^{33}$ Reductions in MSDBP and MSSBP levels were comparable for the aliskiren/ valsartan combinations and their respective component monotherapies. ${ }^{33}$ Responder rates with aliskiren monotherapy $(P<0.05$, aliskiren $75 \mathrm{mg}$ and $150 \mathrm{mg} ; P<0.001$, aliskiren $300 \mathrm{mg}$ ) and for all aliskiren/valsartan combinations $(P<0.05$, aliskiren $150 \mathrm{mg} /$ valsartan $160 \mathrm{mg} ; P<0.001$, aliskiren $300 \mathrm{mg} /$ valsartan $320 \mathrm{mg}$ ) were significantly greater than with placebo. Responder rates for most combinations did not differ from those for their respective monotherapies. ${ }^{33}$ The reduction in BP and the responder rates with the 2 highest dose combinations were similar to those with the valsartan/HCTZ combination. Rates of BP control did not differ between the aliskiren/valsartan combinations and their component monotherapies. ${ }^{33}$

A phase III study was conducted in 1,797 patients with mild to moderate hypertension who were randomized to once-daily aliskiren $150 \mathrm{mg}$, valsartan $160 \mathrm{mg}$, aliskiren/valsartan $150 \mathrm{mg} /$ $160 \mathrm{mg}$, or placebo for 4 weeks; followed by forced titration to double the dose for another 4 weeks. ${ }^{41}$ At both 4 and 8 weeks, reductions in MSDBP and MSSBP were significantly greater

\section{FIGURE 3a Efficacy of Ramipril or Aliskiren Monotherapy, or Combination Therapy, at 8 Weeks in Patients with Mild to Moderate Hypertension ${ }^{40}$}

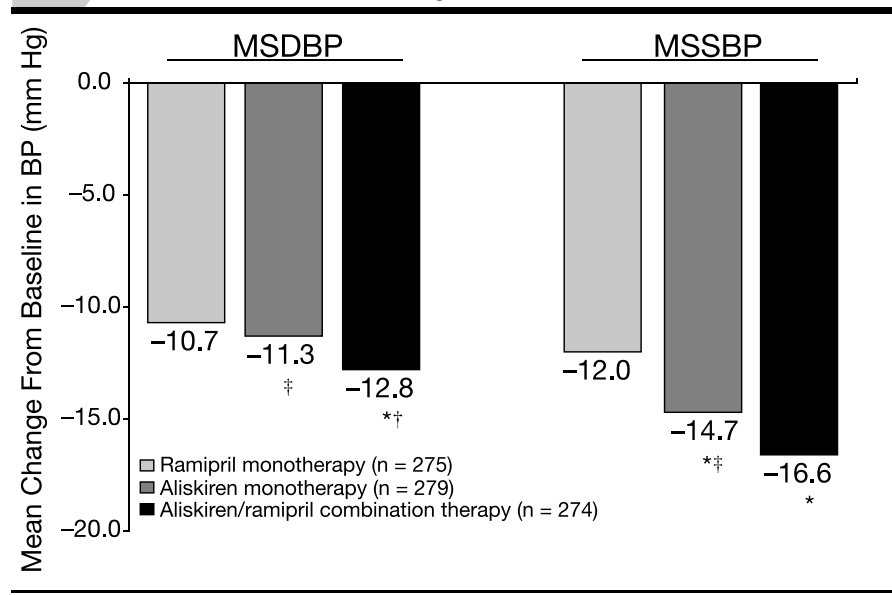

${ }^{*} P<0.05$ for superiority versus ramipril monotherapy.

$\dagger P<0.05$ for superiority versus aliskiren monotherapy.

$\mp P<0.05$ for non-inferiority for aliskiren monotherapy versus ramipril monotherapy $\mathrm{MSDBP}=$ mean sitting diastolic blood pressure; $\mathrm{MSSBP}=$ mean sitting systolic blood pressure.

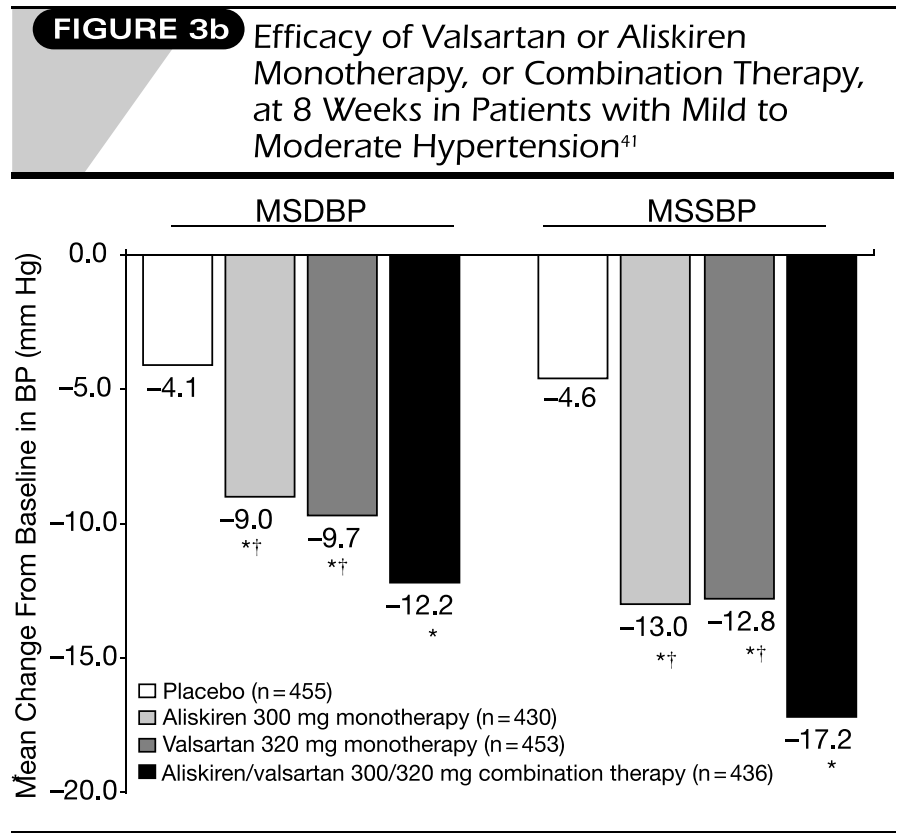

${ }^{*} P<0.0001$ versus placebo

$\dagger P<0.0001$ versus aliskiren/valsartan combination.

$\mathrm{MSDBP}=$ mean sitting diastolic blood pressure; $\mathrm{MSSBP}=$ mean sitting systolic blood pressure

with all active treatments than with placebo $(P<0.0001)$ (Figure 3b). The aliskiren/valsartan combination was significantly more effective than either component alone in reducing MSDBP and MSSBP $(P<0.0001)$, 24-hour mean ADBP and 
ASBP $(P<0.0001)$, and daytime and nighttime mean ADBP. ${ }^{41}$ The aliskiren/valsartan combination provided significantly smoother BP control for a 24-hour period (smoothness index 1.2 vs. 0.9 with either aliskiren or valsartan alone; $P<0.05$ ), with a trough to peak ratio of 0.79 . The combination thus provided additional BP reductions that were maintained for 24 hours.

\section{Safety and Tolerability}

A pooled safety analysis has been conducted on data from 7 randomized double-blind multicenter studies in 4,704 patients with mild to moderate hypertension (monotherapy, 2,598; combination therapy, 2,106) treated with aliskiren $(75 \mathrm{mg}$ to $600 \mathrm{mg}$ ) for 6 to 8 weeks. ${ }^{25}$ In 5 placebo-controlled trials, the overall incidence of adverse events after 52 to 55 days of treatment was similar for aliskiren monotherapy and placebo (39.8\% vs. $40.2 \%$, respectively). ${ }^{25}$ Rates of discontinuation due to adverse events were low and were reported as between $1.7 \%$ and $2.6 \%$ with aliskiren $75 \mathrm{mg}$ to $600 \mathrm{mg}$, respectively, and 3.5\% with placebo. ${ }^{25}$ Overall, the most frequently reported adverse events with aliskiren and placebo were headache (5.7\% vs. $8.7 \% ; P<0.01$ vs. placebo), nasopharyngitis (4.4\% vs. $5.8 \% ; P=\mathrm{NS}$ ), diarrhea ( $2.6 \%$ vs. $1.2 \% ; P<0.05$ vs. placebo), dizziness ( $1.8 \%$ vs. $2.2 \%$; $P=N S)$, and fatigue ( $1.6 \%$ vs. $1.5 \% ; P=N S) .{ }^{25}$ Increased rates of diarrhea were reported mainly for the $600 \mathrm{mg}$ dose of aliskiren (9.5\% vs. $1.2 ; P<0.0001)$ and not at lower doses. ${ }^{25}$ Consequently, the highest recommended dose for aliskiren is $300 \mathrm{mg}$ once daily because of a relatively flat BP response and increased incidence of adverse events with doses higher than $300 \mathrm{mg}$ a day.

In the treatment of patients with severe hypertension, both aliskiren and lisinopril were well tolerated and no differences were noted between groups in the proportion of patients who reported an adverse event, the type of adverse event, or the rate of discontinuation due to an adverse event. ${ }^{37}$

The addition of aliskiren $150 \mathrm{mg}$ or $300 \mathrm{mg}$ to valsartan, amlodipine, HCTZ, or ramipril therapy did not alter the frequency or type of adverse events compared with their respective monotherapies. ${ }^{25}$ In fact, some adverse effects may be avoided with aliskiren therapy when used in combination with other antihypertensive agents. The addition of aliskiren to ramipril therapy reduced the rate of cough (1.8\%) compared with ramipril alone (4.7\%); ${ }^{25}$ in patients receiving aliskiren $150 \mathrm{mg}$ as add-on therapy to amlodipine $5 \mathrm{mg}$, the rate of edema was reduced to $2.1 \%$ compared with a rate of $11.2 \%$ with amlodipine $10 \mathrm{mg} .{ }^{25}$

\section{Place in Therapy of Pharmacologic Direct Renin Inhibition}

Control of hypertension to below-target BP levels is crucial for reducing rates of adverse cardiovascular events. The National Health and Nutrition Examination Survey (1999-2004) showed an overall prevalence of hypertension ( $\mathrm{BP} \geq 140 / 90 \mathrm{~mm} \mathrm{Hg}$ or use of antihypertensive medication) between 2003 and 2004 of $29.3 \%{ }^{42}$ For the same period, rates of BP control were $33 \%$, $64 \%$, and $33 \%$, respectively, for all patients with hypertension, treated patients, and treated patients with diabetes, indicating that the treatment of hypertension remains suboptimal. ${ }^{42}$

Aliskiren administered once daily provides another effective and safe option for the treatment of hypertension as monotherapy. ${ }^{32,34-37}$ However, approximately $70 \%$ of patients with hypertension, particularly high-risk patients with lower BP goals and patients whose BP exceeds SBP or DBP target values by $\geq 20 \mathrm{~mm} \mathrm{Hg}$ or $\geq 10 \mathrm{~mm} \mathrm{Hg}$, respectively, will require combination therapy to achieve BP control. ${ }^{43}$ Aliskiren, which acts at the rate-limiting step in the RAAS pathway, is a logical component of combination therapy, because it enhances RAAS suppression and attenuates the reactive increase in PRA when added to other classes of antihypertensive agents. ${ }^{32}$ Combining agents (such as diuretics, ACEIs, and ARBs) that increase PRA with an agent (such as aliskiren) that neutralizes this activity appears to be a rational approach for optimizing BP control. Combined RAAS inhibition may allow the use of lower doses of each component to achieve more effective and durable RAAS suppression with potentially fewer adverse effects. ${ }^{32,33}$ Patients with severe hypertension, especially those with renal failure, may theoretically benefit from even more intensive RAAS inhibition through the blockade of additional steps of the pathway, but this approach needs further exploration. Table 2 lists some potential therapeutic roles for DRIs in the management of hypertension and its sequelae.

Clinical studies have provided convincing evidence that aliskiren controls RAAS activity, reduces BP significantly, and displays good tolerability. Additionally, as with other RAAS inhibitors, RAAS blockade via direct renin inhibition has the potential to provide organ protection independent of BP reductions. ${ }^{44}$ A robust clinical development program is ongoing to evaluate the renoprotective and cardioprotective effects of aliskiren in which surrogate markers and major clinical outcomes will be analyzed as primary endpoints (Table 3). What may be on the horizon is the use of dual RAAS blockade, which includes

\section{TABLE 2 Potential Therapeutic Role of Direct Renin Inhibitors $22,32,33,44$}

- Monotherapy for hypertension

- Component of combination therapy for hypertension, with a diuretic, a CCB, an ACEI, and/or an ARB

- Alternative to ACEIs or ARBs in the management of hypertension and the prevention of organ damage

- Alternative to ACEIs in patients with diabetic nephropathy or cardiovascular disease

- Use in patients with diabetic nephropathy or in African American hypertensive patients, in whom intrarenal angiotensin II formation occurs via ACE or non-ACE-dependent pathways

$A C E=$ angiotensin-converting enzyme; $A C E I=A C E$ inhibitor $; A R B=$ angiotensin receptor blocker; $C C B=$ calcium channel blocker. 


\section{TABLE 3 Aliskiren Clinical Development Program: Evaluating Surrogate Markers and Clinical Outcomes}

\begin{tabular}{|c|c|c|c|c|}
\hline Trial Name & $\mathbf{N}$ & Objective of Trial & $\begin{array}{c}\text { Length of } \\
\text { Trial }\end{array}$ & Primary Endpoint \\
\hline $\begin{array}{l}\text { AGELESS } \\
\text { Aliskiren versus ramipril for BP } \\
\text { control in the elderly }\end{array}$ & 912 & $\begin{array}{l}\text { Compare the efficacy of aliskiren versus ramipril in } \\
\text { lowering SBP in patients } \geq 65 \text { years of age with systolic } \\
\text { hypertension }\end{array}$ & 36 weeks & Reduction from baseline in MSSBP \\
\hline $\begin{array}{l}\text { AVOID* } \\
\text { Aliskiren in the evaluation of } \\
\text { proteinuria in diabetes }\end{array}$ & 754 & $\begin{array}{l}\text { Determine the effect of adding aliskiren or placebo to } \\
\text { background losartan treatment on proteinuria in diabetic } \\
\text { patients }\end{array}$ & 24 weeks & Percent reduction in UACR \\
\hline $\begin{array}{l}\text { ALLAY } \\
\text { Aliskiren left ventricular assessment } \\
\text { of hypertrophy }\end{array}$ & 480 & $\begin{array}{l}\text { Determine the effect of aliskiren alone or in } \\
\text { combination with losartan on the regression of left ven- } \\
\text { tricular mass in overweight hypertensive patients }\end{array}$ & 34 weeks & Change in left ventricular mass \\
\hline $\begin{array}{l}\text { AVANT GARDE (TIMI 43) } \\
\text { Aliskiren and valsartan versus } \\
\text { placebo in lowering NT-proBNP in } \\
\text { patients stabilized following an ACS }\end{array}$ & 1,152 & $\begin{array}{l}\text { Determine whether aliskiren, valsartan, or combination } \\
\text { therapy will improve ventricular remodeling in high-risk } \\
\text { patients who have been stabilized following ACS }\end{array}$ & 9 weeks & $\begin{array}{l}\text { Reduction of NT-proBNP from } \\
\text { baseline }\end{array}$ \\
\hline $\begin{array}{l}\text { ASPIRE } \\
\text { Aliskiren in post-MI patients to } \\
\text { reduce remodeling }\end{array}$ & 860 & $\begin{array}{l}\text { Determine whether aliskiren attenuates pathological left } \\
\text { ventricular remodeling in high-risk post-MI patients } \\
\text { when added to standard therapy }\end{array}$ & 36 weeks & Change in LVESV by echo \\
\hline $\begin{array}{l}\text { ALOFT* }^{\star} \\
\text { Aliskiren observation of heart failure } \\
\text { treatment }\end{array}$ & 320 & $\begin{array}{l}\text { Determine the safety and tolerability of adding aliskiren } \\
\text { or placebo to standard heart failure treatment in patients } \\
\text { with chronic heart failure }\end{array}$ & 12 weeks & $\begin{array}{l}\text { Tolerability and safety of aliskiren; } \\
\text { change in BNP }\end{array}$ \\
\hline $\begin{array}{l}\text { ALTITUDE } \\
\text { Aliskiren in type } 2 \text { diabetes using } \\
\text { cardiorenal disease endpoints }\end{array}$ & 8,400 & $\begin{array}{l}\text { Determine whether aliskiren with conventional } \\
\text { treatment reduces cardiovascular and renal morbidity } \\
\text { and mortality in high-risk patients with type } 2 \text { diabetes }\end{array}$ & 4 years & $\begin{array}{l}\text { Time to diabetic complications } \\
\text { (secondary prevention trial) }\end{array}$ \\
\hline
\end{tabular}

*Study completed, results pending.

$A C S=$ acute coronary syndrome; $B N P=B$-type natriuretic peptide; $B P=$ blood pressure; echo=echocardiography; $L V E S V=$ left ventricular end systolic volume;

$\mathrm{MI}=$ myocardial infarction; $\mathrm{MSSBP}=$ mean sitting systolic blood pressure; $N T$-proBNP $=\mathrm{N}$-terminal proB-type natriuretic peptide; $S B P=$ systolic blood pressure;

$\mathrm{UACR}=$ urinary albumin/creatinine ratio.

a DRI, as several trials will investigate whether combination therapy provides enhanced protection and improved outcomes over monotherapy.

\section{Summary and Conclusions}

The DRI aliskiren is a new orally available, highly specific, and effective inhibitor of RAAS activity. Both as monotherapy and in combination with a thiazide diuretic, a CCB, an ACEI, or an ARB, aliskiren reduces BP in patients with mild to moderate hypertension. Aliskiren has antihypertensive efficacy comparable with that of these other classes of antihypertensive agents, and counters the reactive increase in PRA when used in combination with these agents. In the treatment of patients with severe hypertension, aliskiren is comparable with lisinopril. Aliskiren has a tolerability profile similar to that of placebo and ARBs and is well tolerated when used in combination with other agents. Further studies will explore its potential as monotherapy or in combination with other antihypertensives, and for uses beyond BP reduction, such as renoprotection and cardioprotection.

\section{DISCLOSURES}

The author discloses no potential bias or conflict of interest relating to this article.

\section{REFERENCES}

1. Nguyen G, Burckle C, Sraer J-D. The renin receptor: the facts, the promise and the hope. Curr Opin Nephrol Hypertens. 2003;12:51-55.

2. Laragh JH, Sealey JE. Relevance of the plasma renin hormonal control system that regulates blood pressure and sodium balance for correctly treating hypertension and for evaluating ALLHAT. Am J Hypertens. 2003;16:407-15

3. Carey RM, Siragy HM. Newly recognized components of the reninangiotensin system: potential roles in cardiovascular and renal regulation. Endocr Rev. 2003;24:261-71.

4. Levy BI. How to explain the differences between renin angiotensin system modulators. Am J Hypertens. 2005;18(9 pt 2):134S-141S.

5. Pagliaro P, Penna C. Rethinking the renin-angiotensin system and its role in cardiovascular regulation. Cardiovasc Drugs Ther. 2005;19:77-87.

6. Ibrahim MM. RAS inhibition in hypertension. J Hum Hypertens. 2006;20:101-08. 
7. Skeggs LT Jr, Kahn JR, Lentz K, Shumway NP. The preparation, purification, and amino acid sequence of a polypeptide renin substrate. J Exp Med. 1957;106:439-53

8. Muller DN, Fischli W, Clozel JP, et al. Local angiotensin II generation in the rat heart: role of renin uptake. Circ Res. 1998;82:13-20.

9. Nguyen G, Delarue F, Burckle C, Bouzhir L, Giller T, Sraer J-D. Pivotal role of the renin/prorenin receptor in angiotensin II production and cellular responses to renin. J Clin Invest. 2002;109:1417-27.

10. Nguyen G. Renin/prorenin receptors. Kidney Int. 2006;69:1503-06.

11. Danser AH, van Kats JP, Admiraal PJ, et al. Cardiac renin and angiotensins. Uptake from plasma versus in situ synthesis. Hypertension. 1994:24:37-48

12. Nguyen G, Delarue F, Berrou J, Rondeau E, Sraer J-D. Specific receptor binding of renin on human mesangial cells in culture increases plasminogen activator inhibitor-1 antigen. Kidney Int. 1996;50:1897-903.

13. Huang Y, Wongamorntham S, Kasting J, et al. Renin increases mesangial cell transforming growth factor- $\beta 1$ and matrix proteins through receptor-mediated, angiotensin II-independent mechanisms. Kidney Int. 2006;69:105-13.

14. Nguyen G, Bouzhir L, Delarue F, Rondeau E, Sraer J-D. Evidence of a renin receptor on human mesangial cells: effects on PAIl and cGMP [in French]. Nephrologie. 1998;19:411-16.

15. Burckle CA, Jan Danser AH, Muller DN, et al. Elevated blood pressure and heart rate in human renin receptor transgenic rats. Hypertension. 2006;47(pt 2):552-56.

16. Ichihara A, Hayashi M, Kaneshiro Y, et al. Inhibition of diabetic nephropathy by a decoy peptide corresponding to the "handle" region for nonproteolytic activation of prorenin. J Clin Invest. 2004;114:1128-35.

17. Staessen JA, Li Y, Richart T. Oral renin inhibitors. Lancet. 2006;368:1449-56

18. Wood JM, Maibaum J, Rahuel J, et al. Structure-based design of aliskiren, a novel orally effective renin inhibitor. Biochem Biophys Res Commun. 2003;308:698-705.

19. Wood JM, Schnell CR, Cumin F, Menard J, Webb RL. Aliskiren, a novel, orally effective renin inhibitor, lowers blood pressure in marmosets and spontaneously hypertensive rats. J Hypertens. 2005;23:417-26.

20. Pilz B, Shagdarsuren E, Wellner M, et al. Aliskiren, a human renin inhibitor, ameliorates cardiac and renal damage in double-transgenic rats. Hypertension. 2005;46:569-76

21. Nussberger J, Wuerzner G, Jensen C, Brunner HR. Angiotensin II suppression in humans by the orally active renin inhibitor aliskiren (SPP100): comparison with enalapril. Hypertension. 2002;39:el-e8.

22. Azizi M, Menard J, Bissery A, et al. Pharmacologic demonstration of the synergistic effects of a combination of the renin inhibitor aliskiren and the $\mathrm{AT}_{1}$ receptor antagonist valsartan on the angiotensin II-renin feedback interruption. J Am Soc Nephrol. 2004;15:3126-33.

23. Zhao C, Vaidyanathan S, Yeh C-M, Maboudian M, Armin Dieterich $\mathrm{H}$. Aliskiren exhibits similar pharmacokinetics in healthy volunteers and patients with type 2 diabetes mellitus. Clin Pharmacokinet. 2006;45:1125-34

24. Vaidyanathan S, Jermany J, Yeh C, Bizot M-N, Camisasca R. Aliskiren, a novel orally effective renin inhibitor, exhibits similar pharmacokinetics and pharmacodynamics in Japanese and Caucasian subjects. Br J Clin Pharmacol. 2006;62:690-98.

25. Weir MR, Bush C, Anderson DR, Zhang J, Keefe D, Satlin A.

Antihypertensive efficacy, safety and tolerability of the oral renin inhibitor aliskiren in patients with hypertension: a pooled analysis. J Am Soc Hypertens. 2007;1:264-77.
26. Dieterle W, Corynen S, Vaidyanathan S, Mann J. Pharmacokinetic interactions of the oral renin inhibitor aliskiren with lovastatin, atenolol, celecoxib and cimetidine. Int J Clin Pharmacol Ther. 2005;43:527-35.

27. Vaidyanathan S, Valencia J, Kemp C, et al. Lack of pharmacokinetic interactions of aliskiren, a novel direct renin inhibitor for the treatment of hypertension, with the antihypertensives amlodipine, valsartan, hydrochlorothiazide (HCTZ) and ramipril in healthy volunteers. Int J Clin Pract. 2006;60:1343-56

28. Zhao C, Vaidyanathan S, Dieterich HA, Yeh C, Howard D, Dole WP. Assessment of the pharmacokinetic interaction between the oral direct renin inhibitor aliskiren and furosemide: a study in healthy volunteers [abstract]. Clin Pharmacol Ther. 2007;81(suppl 1):S110.

29. Vaidyanathan S, Reynolds C, Yeh C-M, et al. Pharmacokinetics, safety, and tolerability of the novel oral direct renin inhibitor aliskiren in elderly healthy subjects. J Clin Pharmacol. 2007;47:453-60.

30. Vaidyanathan S, Warren V, Yeh C, Bizot MN, Dieterich HA, Dole WP Pharmacokinetics, safety, and tolerability of the oral renin inhibitor aliskiren in patients with hepatic impairment. J Clin Pharmacol. 2007:47:192-200.

31. Vaidyanathan S, Bigler H, Yeh C-M, et al. Safety, tolerability and pharmacokinetics of the oral direct renin inhibitor aliskiren alone and in combination with irbesartan in renal impairment. Clin Pharmacol Ther. 2007;46:661-75

32. Villamil A, Chrysant SG, Calhoun D, et al. Renin inhibition with aliskiren provides additive antihypertensive efficacy when used in combination with hydrochlorothiazide. J Hypertens. 2007;25:217-26.

33. Pool JL, Schmieder RE, Azizi M, et al. Aliskiren, an orally effective renin inhibitor, provides antihypertensive efficacy alone and in combination with valsartan. Am J Hypertens. 2007;20:11-20.

34. Stanton A, Jensen C, Nussberger J, O'Brien E. Blood pressure lowering in essential hypertension with an oral renin inhibitor, aliskiren. Hypertension. 2003;42:1137-43.

35. Gradman AH, Schmieder RE, Lins RL, Nussberger J, Chiang Y, Bedigian MP. Aliskiren, a novel orally effective renin inhibitor, provides dose-dependent antihypertensive efficacy and placebo-like tolerability in hypertensive patients. Circulation. 2005;111:1012-18.

36. Oh B-H, Mitchell J, Herron JR, Chung J, Khan M, Keefe DL. Aliskiren, an oral renin inhibitor, provides dose-dependent efficacy and sustained 24-hour blood pressure control in patients with hypertension. J Am Coll Cardiol. 2007:49:1157-63.

37. Strasser RH, Puig JG, Farsang C, Croket M, Li J, van Ingen H. A comparison of the tolerability of the direct renin inhibitor aliskiren and lisinopril in patients with severe hypertension. J Hum Hypertens [serial online]. May 31, 2007:doi:10.1038/sj.jhh.1002220.

38. Jordan J, Engeli S, Boye SW, Le Breton S, Keefe DL. Direct renin inhibition with aliskiren in obese patients with arterial hypertension. Hypertension. 2007;49:1047-55

39. Drummond W, Munger MA, Essop MR, Maboudian M, Khan M, Keefe DL. Antihypertensive efficacy of the oral direct renin inhibitor aliskiren as add-on therapy in patients not responding to amlodipine monotherapy. J Clin Hypertens. 2007;9:742-50.

40. Uresin Y, Taylor A, Kilo C, et al. Aliskiren, a novel renin inhibitor, has greater BP lowering than ramipril and additional BP lowering when combined with ramipril in patients with diabetes and hypertension. Abstract presented at: 16th European Meeting on Hypertension; June 12-15, 2006; Madrid, Spain.

41. Oparil S, Yarows SA, Patel S, Fang H, Zhang J, Satlin A. Efficacy and safety of combined use of aliskiren and valsartan in patients with hypertension: a randomised, double-blind trial. Lancet. 2007;370:221-29. 
42. Ong KL, Cheung BMY, Man YB, Lau CP, Lam KSL. Prevalence, awareness, treatment, and control of hypertension among United States adults 1999-2004. Hypertension. 2007;49:69-75.

43. Pool JL. Is it time to move to multidrug combinations? Am J Hypertens. 2003;16:36S-40S.
44. Stanton A. Therapeutic potential of renin inhibitors in the management of cardiovascular disorders. Am J Cardiovasc Drugs. 2003;3:389-94. 